\title{
FISHERIES ABUNDANCE OF THE LINE AND HOOK SMALL SCALE FISHERIES OF THE CENTRAL COAST OF BRAZIL
}

\author{
Adriano Prysthon da SILVA \\ Embrapa Pesca e Aquicultura
}

*email: adriano.prysthon@embrapa.br

Recebido em 10/07/2017

Resumo - A challenge of the marine small-scale fisheries (SSF) that requires immediate attention is the uncertainty of how the activity affects and is affected by the changes in ecological and social dynamics. Understanding the fisheries dynamics and strategies allows not only the comprehension of fish yield seasonality but also provides subsidies for the ecosystem approach of fisheries (EAF) on the possible impacts it may cause. This study aimed to describe the fishery dynamics of the hook and line fisheries on the major stocks exploited by SSFs on the central coast of Brazil (BaixoSul region, Bahia). 5,092 landings by the SSF fleet were evaluated between 2004 and 2008. The main abundance index (annual and monthly average CPUE) was evaluated and compared (ANOVA and Tukey at 5\%) and the main groups species caught are pelagic and bottom ones. The finding that (i) the high selectivity of hook and line and absence of bycatch and, (ii) the stability of the monthly mean CPUE indicated that the hook and line SSF in the region studied may not significant environmental impact. This result emphasizes the importance that the information generated may represent for the decision making process to confront the possible impacts and conflicts of the use of the marine coastal environment, as well as the need for the effective participation of fishers in the co-management models in the future and improve better public policies aimed at the fisherfolks. These results also contribute to the construction of comanagement models based on EAF.

Palavras-Chave: Fisherfolks, Co-management, low-impact

\section{ABUNDÂNCIA PESQUEIRA DAS LINHAS E AZÓIS NA PESCA DE PEQUENA ESCALA DA COSTA} CENTRAL DO BRASIL

Resumo - Um desafio da pesca artesanal marinha que requer imediata atenção está ligado à incerteza de como a atividade afeta e é afetada pelas mudanças nas dinâmicas ecológicas e sociais. Neste estudo, objetivou-se descrever a dinâmica pesqueira das linhas e anzóis nos principais estoques explorados na costa central do Brasil. 5092 desembarques da frota artesanal de linha foram avaliados entre 2004 e 2008. O principal índice de abundância (CPUE média anual e mensal) foi avaliado e comparado (ANOVA e Tukey, $\mathrm{p} \geq 0.005$ ) e as principais espécies capturadas são pelágicas e as de fundo. Verificou-se que (i) a alta seletividade da linha e ausência de fauna acompanhante neste estudo e (ii) a estabilidade das CPUE mensais na comparação e médias, indica que a pesca artesanal de linha, na região do baixo-Sul da Bahia, Brazil, pode não provocar um impacto ambiental significativo. Esta conclusão enfatiza a relevância que o conjunto de informações geradas possa representar para o processo de tomada decisão frente a possíveis impactos e conflitos de uso do ambiente costeiro marinho, bem como a necessidade de participação efetiva dos pescadores nos futuros modelos de gestão e subsidiando melhores políticas públicas voltadas ao setor pesqueiro. Estes resultados contribuem ainda para a construção de modelos de comanejo baseado na abordagem ecossistêmica.

Palavras-chave: Pescadores, Co-manejo, Baixo impacto 


\section{INTRODUCTION}

The definition of artisanal or small-scale fisheries (SSF) necessarily includes the recognition that its main actors represent $99 \%$ of the world's fishers and that the activity contributes significantly to food security, poverty alleviation and the cultural appreciation of millions of people around the world (FAO 2015). In developing countries, fisheries still provide animal protein for over 1 billion people (BENE 2006). Despite recognition, the contribution from small-scale fisheries has not been quantified in regional and national economies (UNDP 2005). In addition, one challenge in marine SSF that requires immediate attention is the uncertainty of how the activity affects and is affected by the changes in the ecological and social dynamics (MCCONNEY et al., 2014).

The widespread degradation scenario of marine coastal ecosystems has been the main factor in the reduction of the stocks exploited by fishing communities and threatens the perpetuation of the activity. The main challenges faced by SSF include: (i) agricultural pollution by fertilizers and pesticides (FAO 2003), (ii) industrial and urban pollution ( ERIKSEN et al. 2014, FISHERMEN 2014); (iii) removal of riparian forests, increased turbidity and suspended matter in the coastal zone, with a direct impact on coral reef and primary productivity; (iv) disorderly occupation of the coastline including the removal of mangroves, dunes and salt marshes, (v) cultural distortion of the fishing communities caused by migration and territorial reorganization (TRIMBLE \& JOHNSON 2013, SILVA 2012), and lack and/or inefficient management of the marine resources by the government, among others.

In addition, events such as climate changes, e.g., changes in sea level (CABANES et al. 2001), in ocean temperature and ocean acidification (HOEGH-GULDBERG et al. 2007) affect primary productivity and shift the composition and ecological trophic habitats (HOBDAY et al. 2015; KATSELIS et al. 2013). In the global scale, the impacts from climate changes on fisheries may include large redistribution in the catch potential, with $40 \%$ reduction in tropical regions (CHEUNG et al. 2010). Overfishing is commonly reported as a factor that contributes to the reduction of fish stocks, particularly in the industrial fisheries (BEARZI et al. 2006, HILBORN \& HILBORN, 2012). The impacts of fishing pressure on marine ecosystems have shown that fisheries resources are finite. The overall fishing effort is at least two times above the allowed capacity (COLL et al. 2008, PAULY et al. 2002) and fisheries management depends directly on the reduction of fishing effort (ANTICAMARA et al. 2011). Stergiou (2002) reported the consequences of overfishing, such as decrease in the fish size and the early maturity of commercial 
species. Many studies may be found in the literature discussing the effects of incidentally caught bycatch from industrial fisheries, with severe impacts on marine populations - causing significant economic losses since 1990s (DAYTON et al. 1995). However, it is worth noting that overfishing is a problem that concerns the production chain, since the international certification mechanisms until the volition by the final consumer (LOGAN et al. 2008).

In developed countries, even though SSF plays an important social role, it has received little or no research attention because of its relatively low economic value (GUYADER et al. 2007, 2013). In developing countries, further to the reason mentioned above, factors such as the high level of labor involved, the lack of adequate policies, and marginalization have contributed to social isolation and economic decline of the sector (FAO 2005). Historically, in Brazil, this negative image also results in little research on the impact of fishing on the stocks. This deficiency is aggravated by the researchers' lack of field experience and the discontinuation of financial support for research (SALAS et al. 2007). Additionally, different fishing gears used in SSF interact in different ways with the marine ecosystems (MORGAN \& CHUENPAGDEE 2003), making it difficult to standardize methodologies and reducing the chances of finding the answers needed to clarify the impacts of SSF on the environment, particularly in tropical coastal environments.

One of these environments is the central coast of Brazil, called "Baixo-Sul" region, Bahia state. This region encompasses a variety of ecosystems with the highest biodiversity in the world (FISCHER et al. 2007). The diverse marine ecosystems, e.g., beaches, bays, reefs, mangroves, salt marshes and estuarine complexes are sensitive areas and peculiar to this region. The reef environments and associated ecosystems, for example, support fish communities that form the basis of the fisheries in many tropical areas (COSTA et al. 2003). In this context, SSF is presented as one of the most important economic activities for more than 14,000 families distributed in 100 communities in the region (WALTER 2011). Along with agriculture, SSF is the main source of income that plays a significant role in food security. Due to the geomorphologic characteristics of the region, many fishing strategies are used by the communities, specially hook and line, as it is a fishing gear that can be easily purchased or manufactured and allows catching species of high commercial value.

Hook and line is a fishing gear that offers flexible operation in different environments both near and away from the coast, in areas with different types of terrains and depths, such as coral reefs, rocky and muddy bottoms and also on the continental slope and in oceanic areas. In particular, Baixo-Sul coast has a relatively narrow continental shelf, which allows fleets to fish in such environment. Another characteristic of this fishing gear is the high selectivity and the low 
incidence of bycatch or discards. Many species of high commercial value are captured and the relatively low operating cost makes many, generally low-income communities, to engage in this type of fisheries (MARTINS et al. 2005).

Reports on the impacts of fisheries on fish stocks are related to less selective strategies, such as trawling, gill nets and traps (WILLIAMS et al. 2011, SHESTER \& MICHELI 2011, BANARU et al. 2013) and few are directed to SSF. Even assuming that SSF has a low bycatch rate (KELLEHER 2005), further studies are needed to understand the real impacts of hook and line fisheries on stocks captured by SSF. Therefore, understanding hook and line fisheries dynamics allows to not only comprehend seasonality of fish yield and catch composition, but also provide subsidies for an ecosystem approach on the possible impacts caused by the activity. In this context, a participatory, continuous and differentiated approach with the fishing communities was proposed to describe the fishery dynamics of the line and hook small scale fisheries of the central coast of Brazil, in the Baixo-Sul region of Bahia, Brazil. This paper also contribute to improve the coastal management and public policies aimed at the fisherfolks of this region and Brazil.

\section{MATERIAL AND METHODS}

\section{AREA OF STUDY}

The study was conducted in the area known as Baixo Sul, South-Central coast of Bahia, Brazil. Hook and line fishing fleets from nine communities within seven municipalities were monitored between 2004 and 2008 (Figure 1). Landings were registered monthly, except in 2004 and 2005 when no data was collected in June and July, and January and August, respectively. The communities were chosen according to the importance of hook and line fisheries in providing family income and the number of fishers were estimated (Table I). 


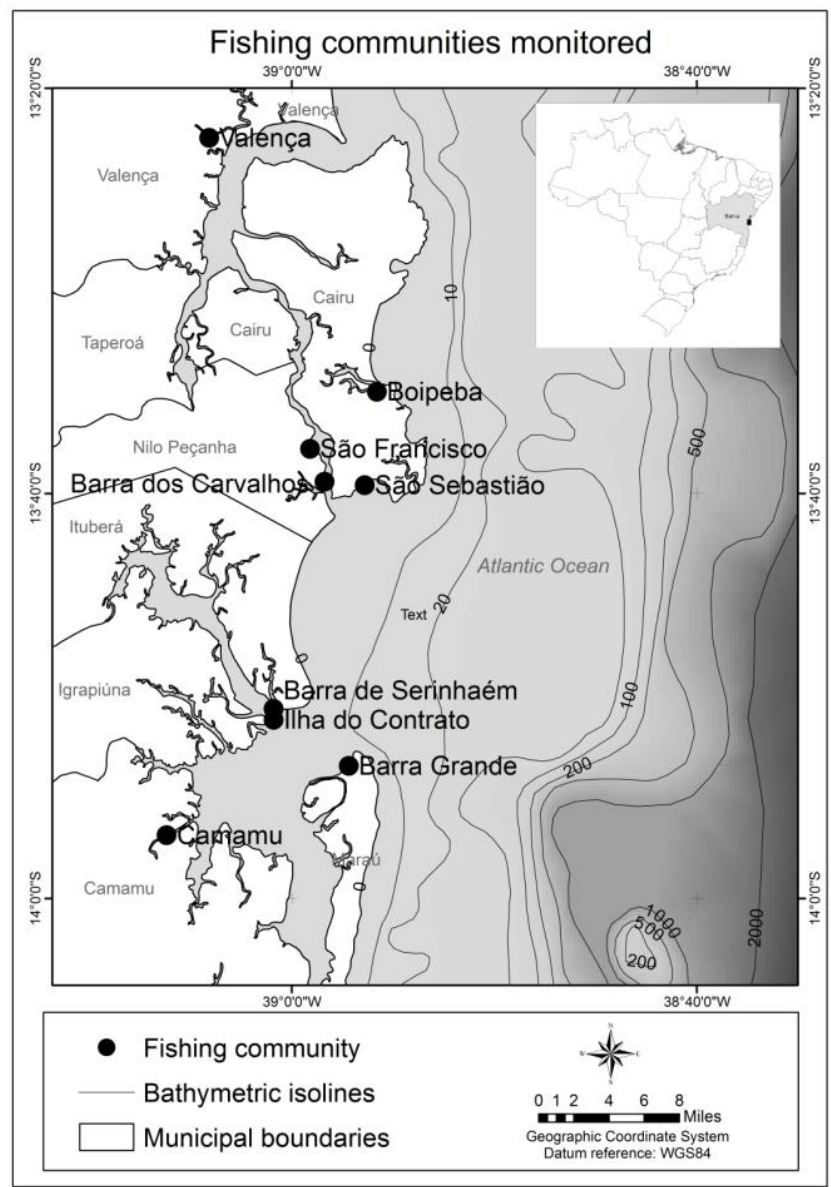

Figure 1. Geographical location of the nine fishing communities studied and their respective municipalities in Baixo Sul, South-Central coast of Bahia, Brazil.

Table 1. Identification, location (lat / long) and estimated fish population of the communities studied.

\begin{tabular}{|c|c|c|c|}
\hline Community/ Municipality & Label & $\begin{array}{l}\text { Geographical points } \\
\text { (Lat/Long) }\end{array}$ & $\begin{array}{c}\text { Fisherfolk } \\
\text { populations } \\
\text { estimated }\end{array}$ \\
\hline Camamu/Camamu & cam & $-13,948 /-39,103$ & 640 \\
\hline Ilha do Contrato/Igrapiúna & Ico & $-13,853 /-39,015$ & 350 \\
\hline Barra de Serinhaém/Ituberá & bse & $-13,844 /-39,01$ & 416 \\
\hline Barra Grande/Maraú & bgr & $-13,891 /-38,953$ & 98 \\
\hline $\begin{array}{l}\text { Barra dos Carvalhos/Nilo } \\
\text { Peçanha }\end{array}$ & bca & $-13,657 /-38,973$ & 120 \\
\hline São Francisco/Nilo Peçanha & sfr & $-13,63 /-38,985$ & 150 \\
\hline
\end{tabular}




\begin{tabular}{lccc}
\hline \hline São Sebastião/Cairu & sse & $-13,66 /-38,94$ & 150 \\
\hline Boipeba/Cairu & boi & $-13,583 /-38,93$ & 112 \\
\hline Valença/Valença & val & $-13,468 /-39,08$ & 2500 \\
\hline
\end{tabular}

\section{FISHING STRATEGY}

Hook and line fisheries is mostly done in wooden motorized and non-motorized vessels. Motorized vessels, known as "saveiros", have greater autonomy to fish in farther coastal areas. They are provided with decks and measure 8 to 11 meters in length and captured fish is kept cooled on ice. Non-motorized boats (canoes) fish within the estuary, measure 4 meters in length and captured fish are usually kept in isothermal boxes. Hook and line fishing predominantly exploit areas between 5 and 120 meters deep, ground and pelagic fish associated with reef environments, continental shelf edges and slopes, and it is the fishing strategy with more sea autonomy than the other strategies employed by the communities. Motorized boats take up to five men onboard and take 1 to 3 hours to reach the fishing areas, known as crowns, stones and/or furrows, and stay fishing for 2-10 days. Non-motorized boats stay out fishing for 1 day. Small pelagic fish, e.g. sardines, are used as bait to catch large pelagic and ground fish. Hook and line fishing includes all manual strategies using bottom or surface lines, and they are also known as hook, "corso" line, hand line, surface line, bottom line, "pindaça", "barandão", "bate-puxa","boiada" and "parada", which are described and illustrated by Olavo et al (2005). Longline fishing, which consists of a main nylon line, fixed on the bottom, with hanging secondary lines with hooks on the tip is included in this category. In this study, all the above mentioned strategies were included and hereinafter referred to as hook and line fisheries. This strategy has a disadvantage, since each modality has a different level of selectivity, which can generate failures in productivity interpretations and capture composition. However, the main objective is to provide the reader with a general overview of how these capture strategies can contribute to the sustainability of exploited stocks and subsidize public policies more adjusted to the fishing sector and the integrate coastal management.

\section{SAMPLING DESIGN AND COMMUNITY APPROACH}

Stratified random sampling was used in this study (Sparre \& Venema 1998), stratum consisted of the fishing strategy (hook and line), and the landing unit was the number of landings per community. This sampling was also used by Silva (2013) in the same region. Daily, individuals at each location collected the landing data. In random sampling it is assumed that the individual collects the data unbiased as the boat arrives to the port without favoring a given boat or fisher. 
The main factors respected in the sampling design were: (i) representativeness of the fleet and the fishing area used by each municipality/community; (ii) the areas of the highest concentration of landings, and (iii) the most favorable conditions to obtain more samples.As previously mentioned, the participatory approach was important in data collection as it recognized the need of the conscious involvement of the fishers in data collection, evaluation and validation. This allowed a gradual appropriation of the information generated, which contributed somehow to the fishers' organization and empowerment (SILVA, 2013). In this way, individuals were nominated by each community controlled landings. They were trained, regularly assessed and supervised monthly by technicians to ensure their motivation and the quality and accuracy of the data.

\section{VARIABLES AND STATISTICAL ANALYSIS}

Data distribution of fish yield was assessed by descriptive analysis with frequency histograms and median boxplots. However, for yield analysis, the catch per unit effort (CPUE) considered was kg/day per landing in each community. The influence of seasonality on fish yield was determined by comparing means between years and months by analysis of variance (ANOVA) and Tukey test at 5\% significant level.

\section{RESULTS AND DISCUSSION \\ EXPLORATORY DATA ANALYSIS}

A total of 5,092 landings were analyzed during the study period. The communities of Boipeba and São Sebastião (both in the municipality of Cairu) presented more landings, 1,197 and 993, respectively (Figure 2), accounting for 43\% of the total landings between 2004 and 2008, whereas less landings (74) were observed in Barra de Serinhaém. Such variation may reflect the fisheries dynamics in the communities, the size of the fishing fleet and the historical and cultural identity associated with hook and line fisheries. Figure 3 presents the landings over the years studied (2004-2008) and shows more landings were observed in 2006 (1,623, 31.8\% of the total), whereas fewer landings were observed in 2004 (506). Considering the number of landings per month, no seasonality trend was observed. Nevertheless, according to the fishers, summer (December to February) and winter (June and July) are the most favorable months to capture highvalue large pelagic and groundfish fish, respectively. The number of landings in July (597) could validate this observation - highest number of landings in the series (Figure 4). Fishers' empirical 
knowledge is an important source of information for the historical understanding of the impacts on the marine environment (Bender et al. 2013).

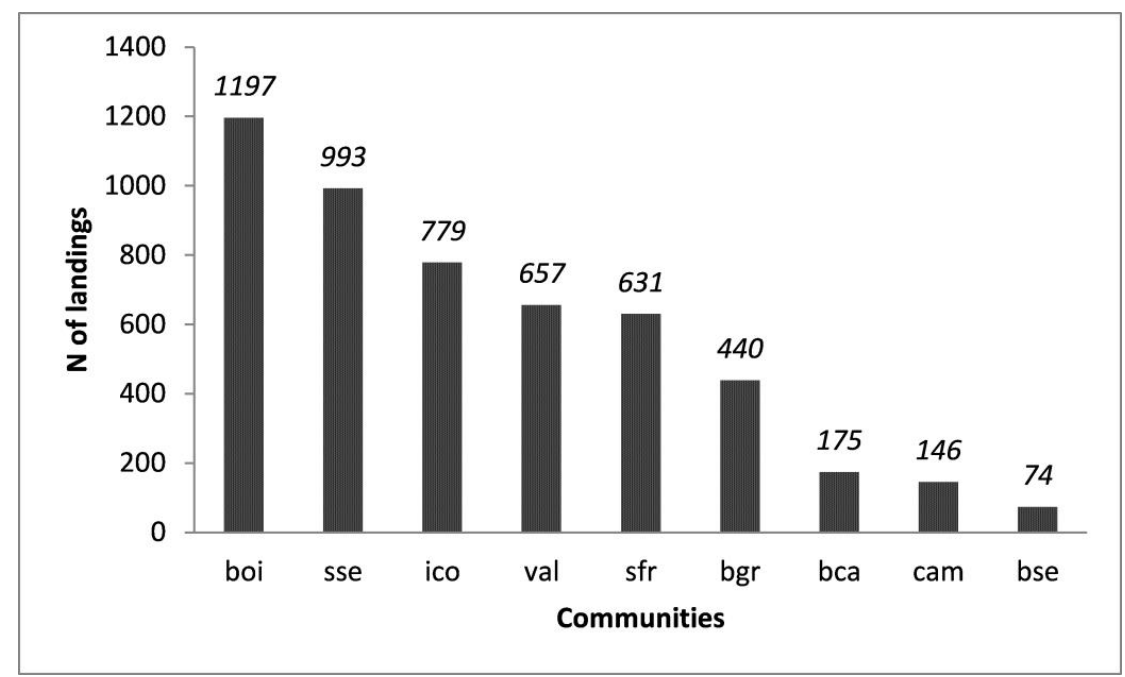

Figure 2. Number of landings per community between 2004 and 2008 (boi=Boipeba; sse=São Sebastião; ico= Ilha do Contrato; val=Valença; sfr=São Francisco; bgr=Barra Grande; bca=Barra dos Carvalhos; cam=Camamu; bse=Barra de Serinhaém).

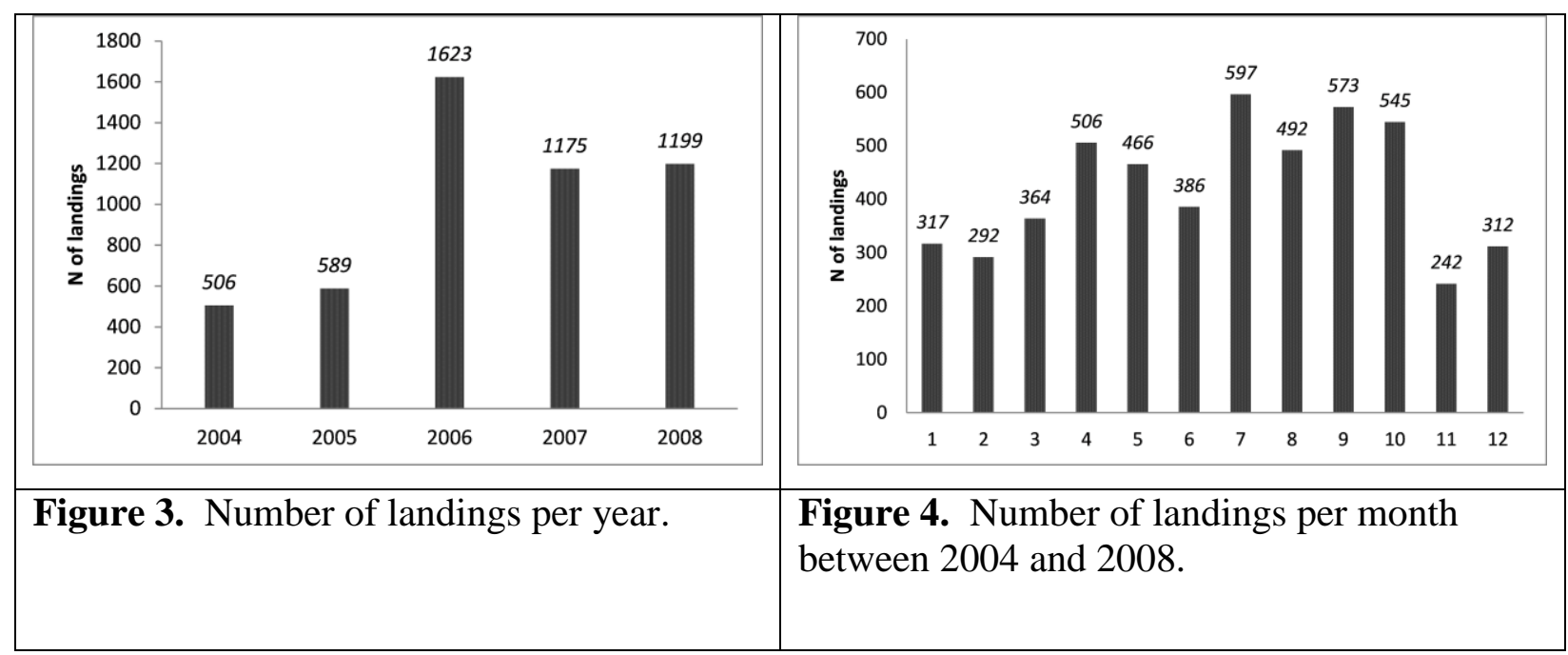

The CPUE values were distributed asymmetrically to the right (Figure 5). Ten-kilogram per day was the class of the highest frequency. This asymmetry is typically observed in SSF, especially in tropical waters. Because of the fishing power of the vessels, the environmental characteristics and the targeted stocks, low catches are more frequent than the high catch events. Furthermore, such asymmetry suggests the use of the median as the most appropriate parameter for the analysis of the spatial and temporal variations. 


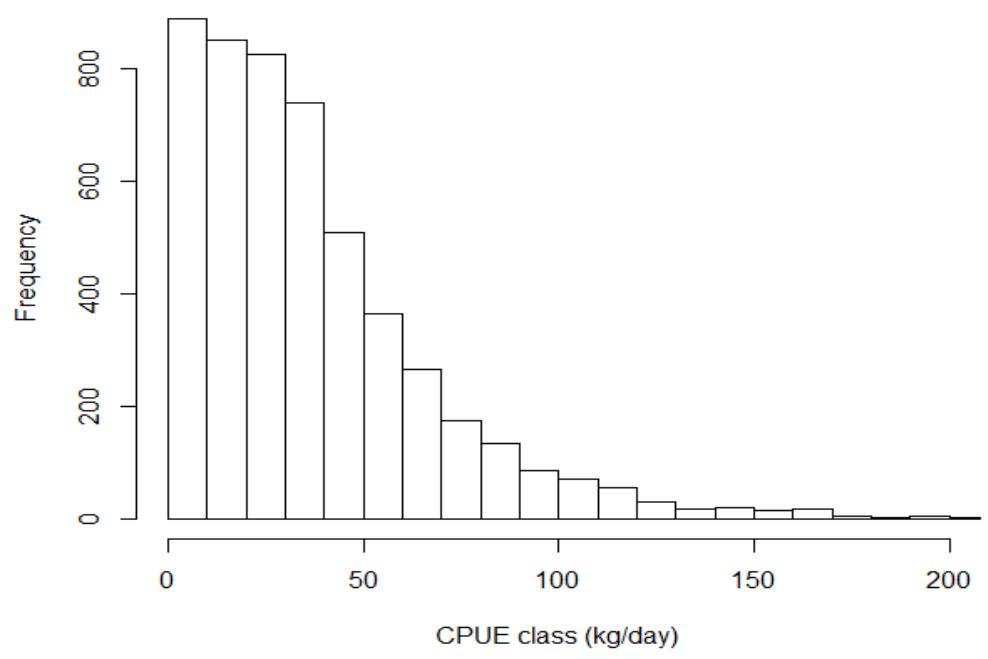

Figure 5. Frequency of landings ( $\mathrm{n}$ ) per class of CPUE (kg /day) of the hook and line fisheries in Baixo Sul, Bahia, Brazil, between 2004 and 2008.

The CPUE box plot analysis of the communities showed that the highest medians were observed in Barra Grande (bgr; 50 kg/day) and Camamu (cam; 45 kg/day) (Figure 6). The highest data dispersions were observed in Barra Grande and São Sebastião. The fishing efficiency in Barra Grande is noteworthy, as there are less fishers and less expeditions than the other communities. The lowest median with low data dispersion was observed in Ilha do Contrato $(8.5 \mathrm{~kg} / \mathrm{day})$, where hook and line fisheries is done only with non-motorized boats in the same fishing grounds for no longer than one day. 2005 was the most efficient year in fish yield, as it presented the highest median and less landings (Figure 7). However, comparing the monthly distribution of yield, January and July presented the highest medians, with 37.8 and $37 \mathrm{~kg} /$ day, respectively (Figure 8). According to the fishers, January and July are the most suitable months to catch pelagic ("summer species") and ground ("winter species") fish of high commercial value. This may validate the higher median values in those months and value the fishers' knowledge on fish ecology and behavior, as it influences and is influenced by the fishing strategy (Begossi 2004). In Boipeba, the third highest median among the communities, significant cultural interference from tourism and oil exploitation was observed (Alencar 2011) but hook and line fisheries in this community has withstood for decades even with fewer fishing vessels. 


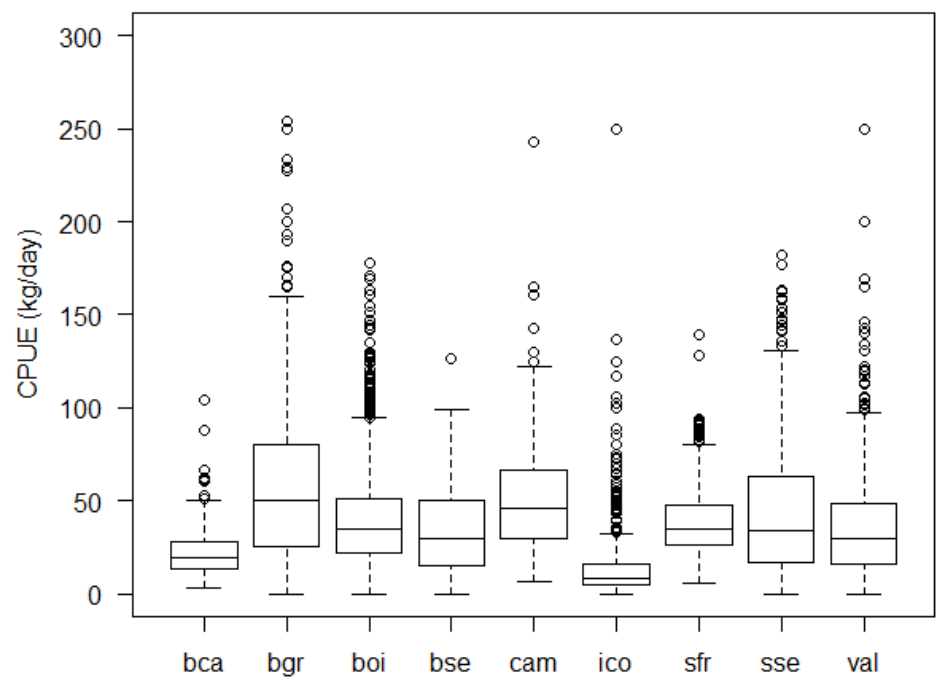

Figure 6. Distribution of CPUE aggregated per community. The boxes represent $50 \%$ of the observations and the black lines represent the median. (bca=Barra dos Carvalhos; bgr=Barra Grande; boi=Boipeba; bse=Barra de Serinhaém; cam=Camamu; ; ico= Ilha do Contrato; sfr=São Francisco; sse=São Sebastião; val=Valença)
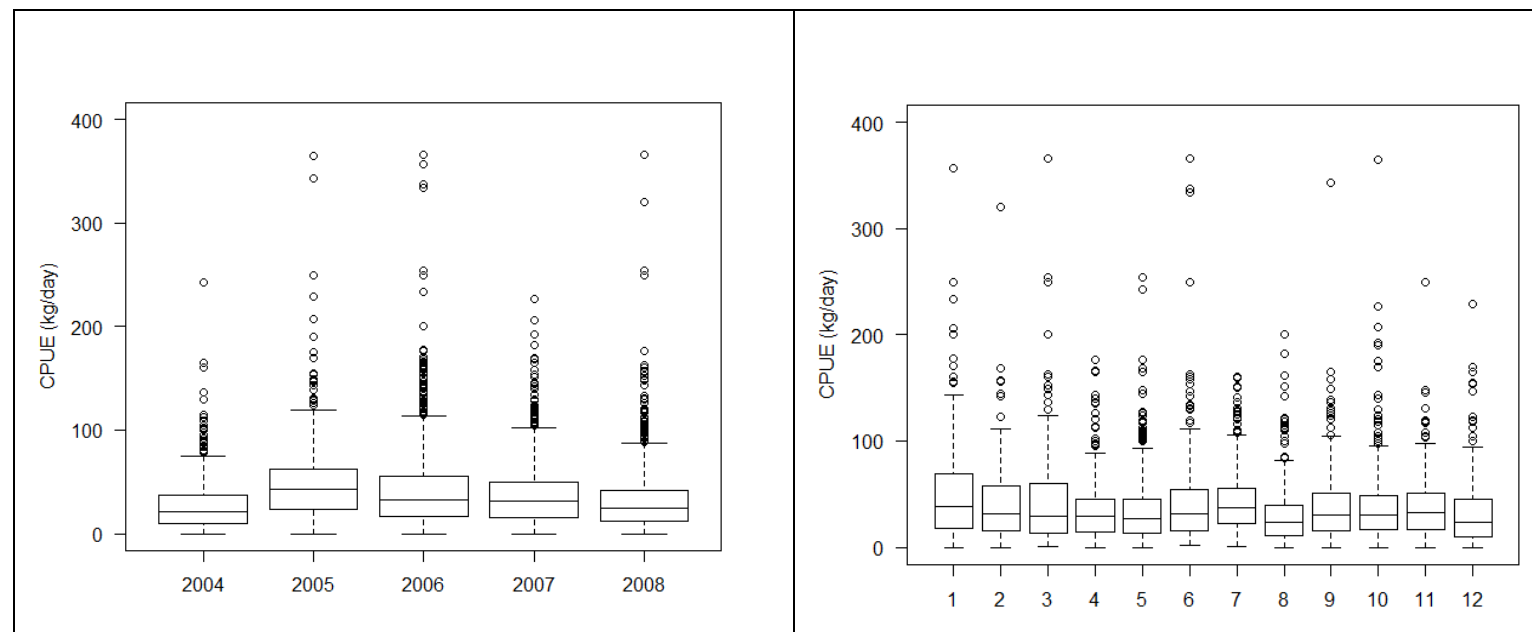

Figure 7. Distribution of CPUE aggregated per year. The boxes represent $50 \%$ of the observations and the black lines represent the median.

Figure 8. Distribution of CPUE aggregated per month. The boxes represent $50 \%$ of the observations and the black lines represent the median. 
Mean CPUE values were significantly different $(\mathrm{p}<0.05)$ between the years (Figure 9). No significant difference was observed between 2004 and 2008, which demonstrates that even in the most productive years (2005, 2006, and 2007), hook and line fisheries remained stable. In 2005, the second low number of landings and the highest mean CPUE were observed, together with high fish yield, probably due to good weather conditions (summer), with better sailing conditions and efficient catches. High mean CPUE in January was observed (Fig. 10), demonstrating the influence of seasonality (summer) and the high catches of pelagic fishes. No significant difference $(\mathrm{p}>0.05)$ was observed between the other months, which demonstrates stable fishing throughout the rest of the year.

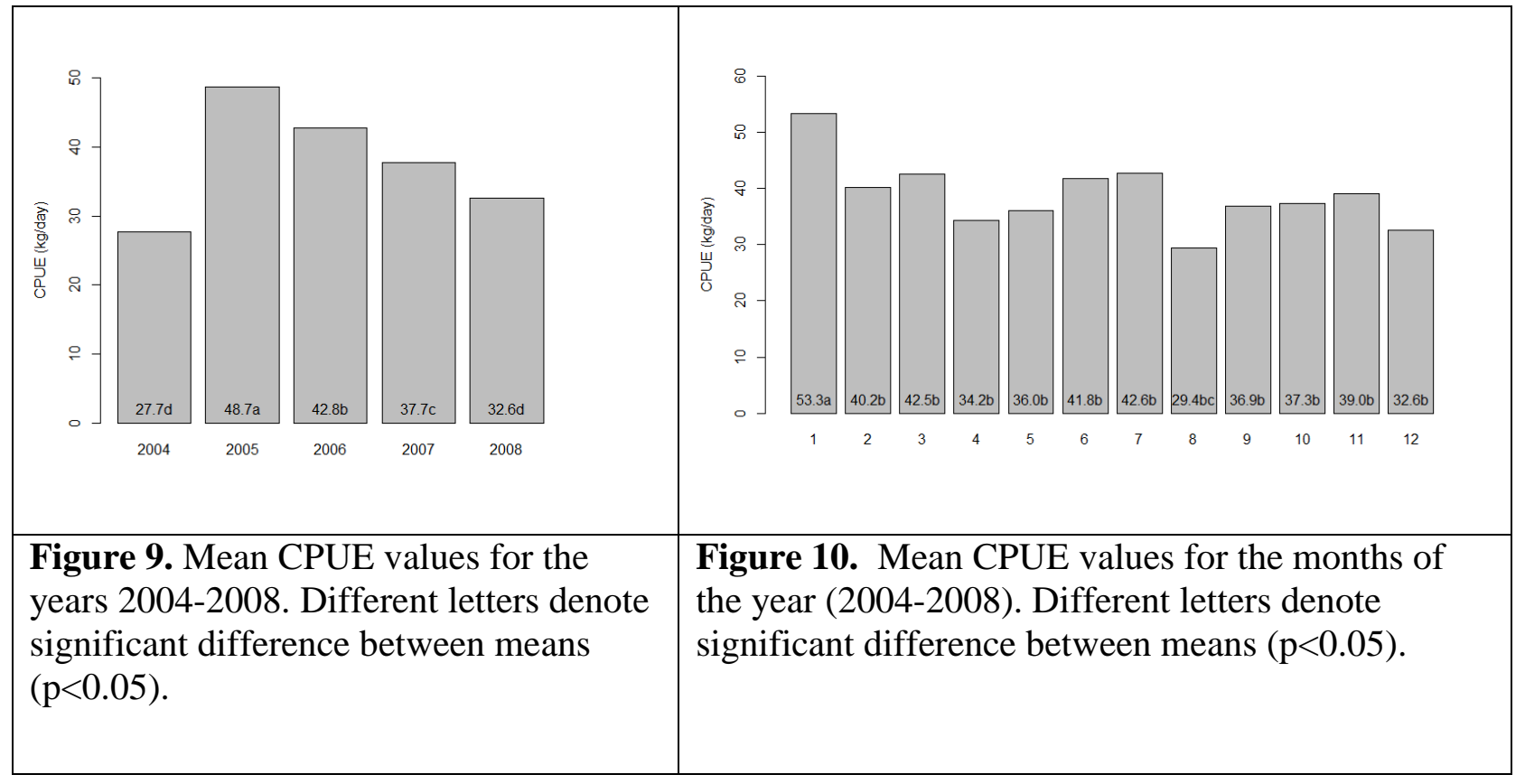

\section{CATCH COMPOSITION}

The pelagic fish species Scomberomorus cavalla and Coryphaena hippurus predominated with 41.5 and 40.4 tons, respectively (Figure 11). Both species are of high commercial value and widely distributed in the western Atlantic (FAO, 1983). Four of the ten most caught species were Lutjanus sp., summing ca. 100 tons, constituting the most captured fish group. The Lutjanus genus is also widely distributed in the tropical western Atlantic (FAO 1985), with high commercial value due to its red body color and good presentation of the meat, especially when marketed fresh. In the Baixo-Sul region, fishers differentiate the Lutjanus species but they are commonly called "vermelho". In the fish species distribution, five were not observed in 2004 (Figure 12). This might be due to the low number of landings in that year (Figure 3). The most representative year for the species was 2006, which coincided with the year with more landings. There was a direct relationship between the number of total landings and the occurrence of the main captured species. 


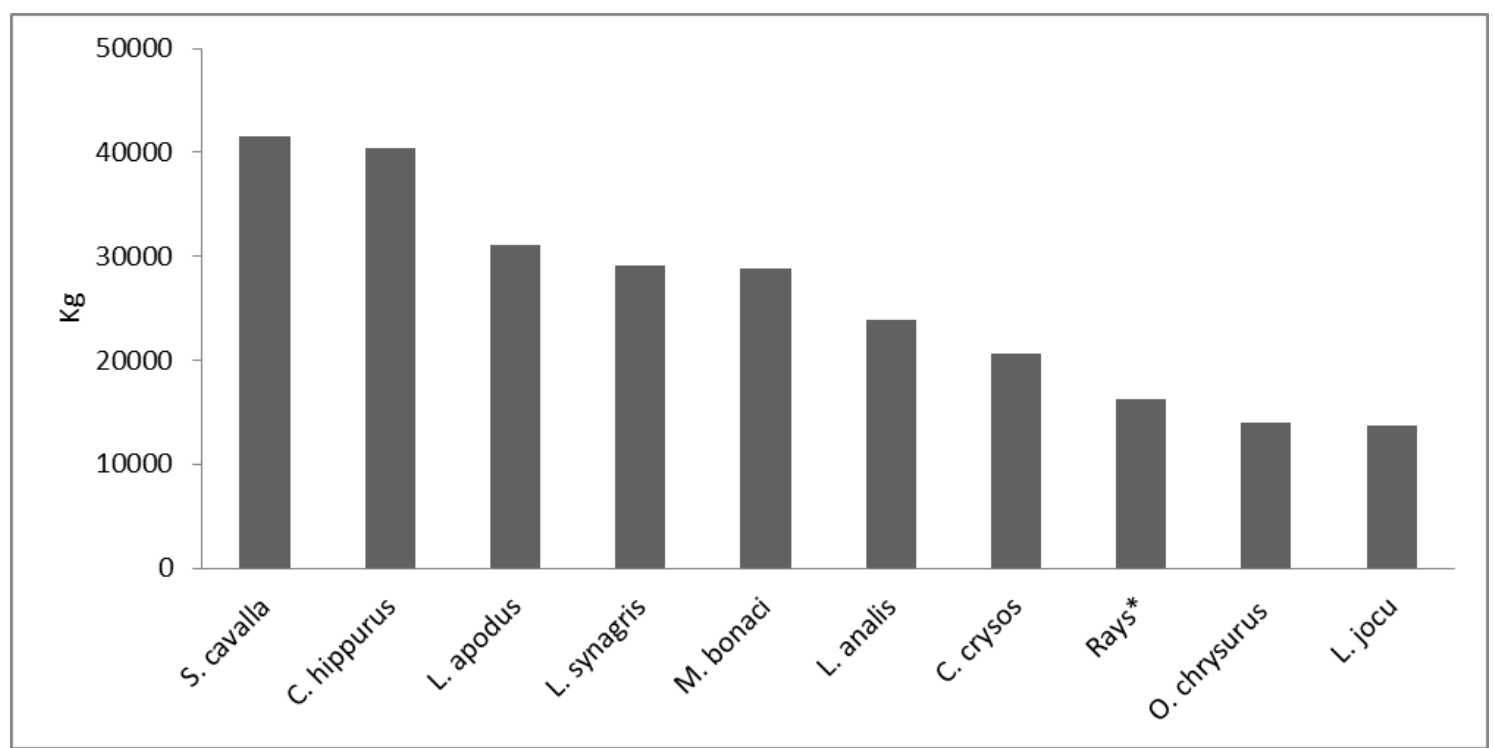

Figure 11. Ten most captured species (kg) by hook and line fishing, in Baixo-Sul region, between 2004 and 2008 (*species aggregated, as not differentiated by the fishers).

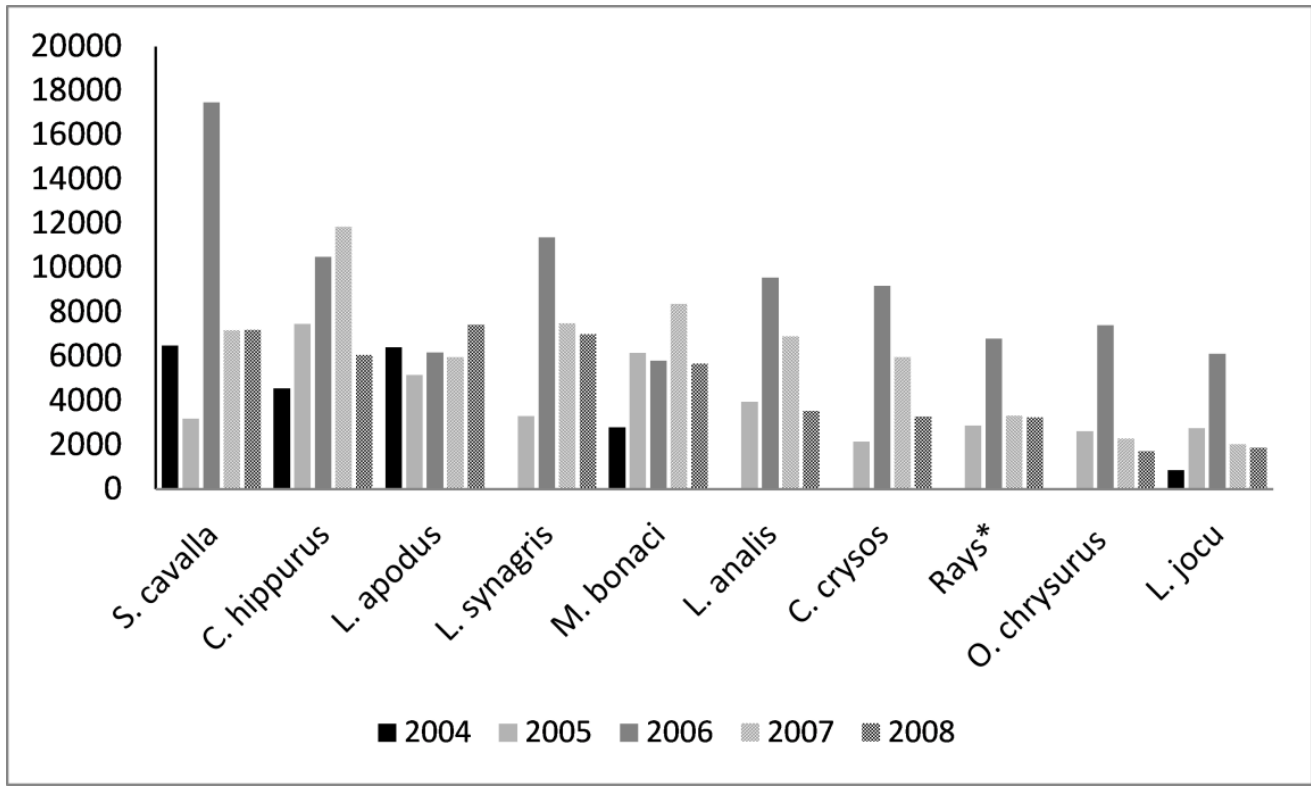

Figure 12. Main species distribution (kg) per year captured by hook and line fishing (*species aggregated, as not differentiated by the fishers).

\section{CONCLUSION}

Considering (i) the high selectivity of the line fisheries and the absence of bycatch in this study, (ii) the stability of the mean monthly CPUEs, it may be concluded that artisanal line 
fisheries in the Baixo-Sul region in Bahia, Brazil, does not cause significant environmental impact to the coastal. However, more studies on capture composition (main pelagic and bottom ones), population dynamics and migration of main species need to be performed in order to confirm this premise. The relative equilibrium of the stocks exploited by line fisheries fleet contributes to the management model based on the ecosystem approach, playing an important role in the management of fisheries, resources and poverty alleviation. This study emphasizes the importance that all the generated information may play in the process of decision-making, in cases of possible conflicts of use and impacts on the marine environment. Additionally, this study aimed at contributing to the construction of more efficient management and conservation models, as current models may be conventional and not suitable in Brazil. Thus, the environmental, economic and social feasibility of small-scale line fisheries depends on a number of factors including the effective participation of local fisheries representatives in the management model. Traditional knowledge and small-scale fisheries together can help elucidate still unknown aspects and contribute to the sustainability of line fisheries in the marine ecosystems coastal.

\section{ACKNOWLEDGEMENTS}

To Drs. Magda Vieira Benavides and Rosiana Rodrigues Alves for the assistance in the statistical analysis, and to M.Sc. Marta Eichemberger Ummus for the maps, all three from the Brazilian Agricultural Research Corporation - Embrapa.

\section{REFERENCES}

ALENCAR, C. M. 2011. Tensões entre pesca, turismo e exploração de gás reconfigurando ruralidade na ilha de Boipeba - BA. Desenvolvimento e Meio Ambiente, 23: 1-18.

ANTICAMARA, J. A., WATSON, R., GELCHU, A. \& PAULY, D. 2011. Global fishing effort (1950-2010): Trends, gaps, and implications. Fish Res, 107: 131-136.

BANARU, D., MELLON-DUVAL, C., ROOS, D \& BIGOT, J. L; SOUPLET, A ; JADAUD, A ; BEAUBRUN, P. ; FROMENTIN, J. M. 2013.Trophic structure in the Gulf of Lions marine ecosystem (north-western Mediterranean Sea) and fishing impacts. Journal of Marine Systems, 111-112: 45-68.

BEARZI, G., POLITI, E., AGAZZI, S. \& AZZELLINO, A. 2006. Prey depletion caused by overfishing and the decline of marine megafauna in eastern Ionian Sea coastal waters (central Mediterranean). Biological conservation, 127: 373-382.

BEGOSSI, A. (Org.). 2004. Ecologia de pescadores da Mata Atlântica e da Amazônia. São Paulo: Hucitec: Nepam/Unicamp: Nupaub/USP: Fapesp, 332 p. 
BENE, C. 2006. Small-scale fisheries: assessing their contribution to rural livelihoods in developing countries. FAO Fisheries Circular, No. 1008 FIPL/C1008 (En).

BENDER, M. G., FLOETER S. R. \& HANAZAKI, N. 2013. Do traditional fishers recognise reeffish species declines? Shifting environmental baselines in Eastern Brazil. Fisheries Management and Ecology, 20: 58-67.

CABANES, C., CAZENAVE, A. \& LE PROVOST, C. 2001. Sea Level Rise During Past 40 Years Determined from Satellite and in Situ Observations. Science, 294 (5543): 840-842.

CHEUNG, W. W. L., LAM, V. W. Y., SARMIENTO, J. L., KEARNEY, K., WATSON, R., ZELLER, D. \& PAULY, D. 2010. Large-scale redistribution of maximum fisheries catch potential in the global ocean under climate change. Global Change Biology, 16: 24-35.

COLL, M., LIBRAlATO, S., TUDELA, S., PALOMERA, I. \& PRANOVI, F. 2008. Ecosystem Overfishing in the Ocean. PLoS ONE, 3(12): e3881.

COSTA, A.S., BRAGA, A.C. \& ROCHA, L.O.F. 2003. Reef fisheries in Porto Seguro, eastern Brazilian coast. Fisheries Research, 60: 577-583.

Dayton, P . K., Thrush, S. F., Agardy, M. T. \& Hofman, R. J. 1995. Environmental effects of marine fishing. Aquatic Conservation: Marine and Freshwater Ecosystems, 5,205-232.

ERIKSEN, M., LEBRETON, L. C. M., CARSON, H. S., THIEL, M. \& MOORE, C. J. 2014. Plastic pollution in the World's Oceans: More than 5 Trillion Plastic Pieces Weighing over 250,000 Tons Afloat at Sea. PLoS ONE 9(12): e111913.

FAO, 2015. Strategy for Improving Information on Status and Trends of Capture Fisheries - Web site. Small-scale fisheries. FI Institutional Websites. In: FAO Fisheries and Aquaculture Department. Rome. Updated . (Accessed 02/03/2015).

FAO, 2005. Increasing the contribution of small-scale fisheries to poverty alleviation and food security. FAO Technical Guidelines for Responsible Fisheries, No. 10. Rome, FAO, 79 pp.

FAO. 2003. Garcia, S.M., Zerbi, A., Aliaume, C., Do Chi, T. \& Lasserre, G. The ecosystem approach to fisheries. Issues, terminology, principles, institutional foundations, implementation and outlook. FAO Fisheries Technical Paper. No. 443. Rome, FAO. 2003. 71 p.

FAO. 1985. species catalogue. Vol. 6. Snappers of the world. An Annotated and Illustrated Catalogue of Lutjanid. Species Known to Date. G-R. Allen - 1985. Fisheries Synopsis, 125: 6.

FAO.1983. Species Catalogue. Vol.2. Scombrids of the world. An annotated and illustrated catalogue of Tunas, Mackerels, Bonitos and related species known to date.Col 1 et t e, B.B. \& C.E. Nauen 1983. FAO Fish. Synop., (125)Vol .2: 137 p.

FISCHER, F. 2007. Baixo Sul da Bahia: uma proposta de desenvolvimento territorial. CIAGS/UFBA, Salvador, 224 p. 
FISHERMEN, J. M. 2014. How to extend do small scale fishing and the aquatic environment impact each other? 162pp.In: McConney, P., R. Medeiros and M. Pena. Ed. Enhancing Stewardship in Small-Scale Fisheries: Practices and Perspectives. Too Big To Ignore (TBTI) and Centre for Resource Management and Environmental Studies, The University of the West Indies, Cave Hill Campus, Barbados. CERMES Technical Report No. 73.

GUYADER, O., BERTHOU, P., KOUSTIKOPOUlOS, C., AlBAN, F., DEMANECHE, S., GASPAR, M., ESCHBAUM, R., FAHY, E., TULLY, O., REYNAL, L.\& ALBERT, A. 2007. Small-Scale Coastal Fisheries in Europe, Final report of the contract No FISH/2005/10.

GUYADER, O., BERTHOU, P., KOUSTIKOPOUlOS, C., AlBAN, F., DEMANECHE, S., GASPAR, M., ESCHBAUM, R., FAHY, E., TULLY, O., REYNAL, L., CURTIL, O., FRANGOUDES, K. \& MAYNOU, F. 2013. Small scale fisheries in Europe: A comparative analysis based on a selection of case studies. Fisheries Research. 140: 1-13.

HILBORN, R; HILBORN, U. 2012. Overfishing: What Everyone Needs to Know. Oxford University Press, New York, 141 p.

HOBDAY, A. J., EVANS, K., YOUNG, J. W., ARRIZABALAGA, H., NICOL, S. \& WENG, K. C. 2015. Impacts of climate change on marine top predators: Advances and future challenges. Deep Sea Research Part II: Topical Studies in Oceanography,113: 1-8.

HOEGH-GULDBERG, O., MUMBY, P. J., HOOTEN, A. J., STENECK, R. S., GREENFIELD, P., GOMEZ, E., HARVELL, C. D., SALE, P. F., EDWARDS, A. J., CALDEIRA, K., KNOWLTON, N., EAKIN, C. M., IGLESIAS-PRIETO, R., MUTHIGA, N., BRADBURY, R. H., DUBI, A. \& HATZIOLOS, M. E. 2007. Coral Reefs Under Rapid Climate Change and Ocean Acidification. Science, 318 (5857):1737-1742.

KATSEliS, G. N., MOUTOPOUlOS, D. K., DIMITRIOU, E. N. \& KOUTSIKOPOUlOS, C. 2013. Long-term changes of fisheries landings in enclosed gulf lagoons (Amvrakikos gulf, W Greece): Influences of fishing and other human impacts. Estuarine, Coastal and Shelf Science, 131: 31-40.

KELLEHER, K.2005. Discards in the World's Marine Fisheries. Fisheries Technical Paper 470. Food and Agriculture Organization of the United Nations, FAO, Rome. p. 154.

LOGAN, C. A., ALTER, S. E., HAUPT, A. J., TOMALTY, K. \& PALUMBI, S. R. 2008. An impediment to consumer choice: Overfished species are sold as Pacific red snapper. Biological Conservation, 141 (6): 1591-1599.

MARTINS, A. S., OLAVO, G. \& COSTA, P. A. S. 2005. A pesca de linha de alto mar realizada por frotas sediadas no Espírito Santo, Brasil. Pp 35-55. In: COSTA, P.A.S.; MARTINS, A.S.; OLAVO, G. (Eds.) Pesca e potenciais de exploração de recursos vivos na região central da Zona Econômica Exclusiva brasileira. Museu Nacional, Rio de Janeiro, 248 p.

MORGAN, L. E.; CHUENPAGDEE, R.; 2003. Shifting Gears: Addressing the Collateral Impacts of Fishing Methods in US Waters. Pew Science Series on Conservation and the Environment. Island Press, Washington, DC. 42pp.

MCCONNEY, P., MEDEIROS R. \& PENA, M. Eds. 2014. Enhancing Stewardship in Small-Scale 
Fisheries: Practices and Perspectives. Too Big To Ignore (TBTI) and Centre for Resource Management and Environmental Studies, The University of the West Indies, Cave Hill Campus, Barbados. CERMES Technical Report No. 73. 162pp.

OLAVO, G., COSTA, P. A. S.\& MARTINS, A.S. 2005. Caracterização da pesca de linha e dinâmica das frotas linheiras da Bahia, Brasil. p. 13-34 In: COSTA, P.A.S.; MARTINS, A.S.; OLAVO, G. (Eds.) Pesca e potenciais de exploração de recursos vivos na região central da Zona Econômica Exclusiva Brasileira. Museu Nacional, Rio de Janeiro, 248 p.

PAUly, D., CHRISTENSEN, V., GUÉNETTE, S., PITCHER, T. J. \& SUMAILA, U. R. 2002. Towards sustainability in world fisheries. Nature, 418: 689-695.

SALAS, S., CHUENPAGDEE, R., SEIJO, J.C. \& CHARLES, A. 2007. Challenges in the assessment and management of small-scale fisheries in Latin America and the Caribbean. Fisheries Research, 87: 5-16.

SILVA, E.C. 2012. Territorialidades e conflitos socioambientais no cotidiano da pesca artesanal na comunidade do porto de jatobá - Abreu e Lima - PE. I Seminário Nacional de geoecologia e Planejamento territorial e IV Seminário do Geoplan. Universidade Federal de Sergipe, 11 a 13 de abril de 2012. Conflitos Ambientais e territoriais: Pesca e Petróleo no litoral brasileiro.

SILVA, A. P. 2013Dinâmica da pesca, produtividade e composição de captura da frota motorizada de Valença-BA, Brasil/ Adriano Prysthon da Silva - Palmas : Embrapa Pesca e Aquicultura,.28 p. : il. color. (Boletim de Pesquisa e Desenvolvimento / Embrapa Pesca e Aquicultura, ISSN 2318$1400 ; 1)$

SPARRE, P. \& VENEMA, S. C. 1997. Introdução à avaliação de mananciais de peixes tropicais. Parte 1-Manual. FAO Documento técnico sobre as pescas. N 306/1, Rev. 2. Roma, 404p.

SHESTER, G.G. \& MICHELI, F. 2011. Conservation challenges for small-scale fisheries: Bycatch and habitat impacts of traps and gillnets. Biological Conservation. 144: 1673-1681.

STERGIOU, K.I. 2002. Overfishing, tropicalization of fish stocks, uncertainty and ecosystem management: resharpening Ockham's razor. Fisheries Research, 55: 1-9.

TRIMBLE, M. \& JOHNSON, D. 2013. Artisanal fishing as an undesirable way of life? The implications for governance of fishers' wellbeing aspirations in coastal Uruguay and southeastern Brazil. Marine Policy, 37: 37-44.

UNDP. 2005. United Nations' Development Programme Millennium Development Goals. Accesseable at: http://www.undp.org/mdg/abcs.html (Accessed 04/01/2015).

Walter, T; Wilkinson, J. 2011. Fortalecimento da cadeia produtiva da pesca artesanal no Baixo Sul baiano. Agriculturas, 8 (3): 26-33.

WILliAMS, A., DOWDNEY, J., SMITH, A. D. M. \& HOBDAY, A. J., FULLER, M. 2011. Evaluating impacts of fishing on benthic habitats: A risk assessment framework applied to Australian fisheries. Fisheries Research,112 (3): 154-167 